\title{
Interactive comment on "The Fractional Energy Balance Equation for Climate projections through 2100” by Roman Procyk et al.
}

\section{Roman Procyk et al.}

roman.procyk@mail.mcgill.ca

Received and published: 18 March 2021

The comment was uploaded in the form of a supplement:

https://esd.copernicus.org/preprints/esd-2020-48/esd-2020-48-AC3-supplement.pdf

Interactive comment on Earth Syst. Dynam. Discuss., https://doi.org/10.5194/esd-2020-48, 2020. 